\title{
LEVERAGING HIGHLY RELATIONAL SERVICE PERFORMANCE THROUGH THE PARTICIPATION OF EMPOWERED CUSTOMERS
}

Objective: As highly relational services are so heavily dependent on customer participation, it is relevant to understand how organizations can turn mandatory participation into more productive interaction; and how customer empowerment can be used as a mechanism to enhance participation and subsequently affect service evaluations and behavioral intentions.

Method: Conceptual article analyzing the literature on customer participation and empowerment and presenting a framework that explores the effects of these constructs on service evaluations and behavioral intentions.

Main Result: Service providers that offer opportunities to customers to move from the audience to the stage turn customers into competent partners, empowered-to-act, who can impact processes and outcomes. Under these conditions, the company together with the customer co-create personalized experiences, and the company can achieve a competitive advantage.

Contributions: The distinction between different empowerment mechanisms and their effects on how participation develops in highly relational services contributes to the literature on service marketing, which may consider distinctive effects in models explaining service performance. The article discusses that customer empowerment impact on participation follows an inverted-U curve shape.

Relevance/Originality: The empowerment-to-act mechanism described may contribute to a reduction in value codestruction risk, as customers will be more prepared to assume their roles.

Social and Managerial Implications: Organizations can clarify the effects of chosen strategies to promote customer empowerment; and public policies can also benefit from a more comprehensive understanding of mechanisms influencing customers' behavioral intentions toward institutions, as customers who are more capable of taking decisions are less vulnerable.

Keywords: Co-creation of Value. Service-dominant Logic. Customer Empowerment. Customer Participation. Highly Relational Services.

\section{ALAVANCANDO O DESEMPENHO DE SERVIÇOS ALTAMENTE RELACIONAIS POR MEIO DA PARTICIPAÇÃO DE CLIENTES EMPODERADOS}

Objetivo: Como serviços altamente relacionais dependem da participação do cliente, é relevante entender como as organizações podem transformar uma participação obrigatória em uma interação mais produtiva; e como o empoderamento do cliente pode contribuir para esta participação, influenciando a avaliação do serviço e intenções comportamentais.

Método: Artigo conceitual analisando literatura sobre participação e empoderamento de clientes e apresentando modelo que explora os efeitos desses construtos sobre a avaliação do serviço e intenções comportamentais.

Resultado principal: Prestadores de serviços que oferecem oportunidades aos clientes de passarem da audiência para o palco os transformam em parceiros competentes, empoderados-para-ação, e podem impactar processos e resultados. Assim, a empresa cocria experiências personalizadas com clientes, e alcança maior vantagem competitiva.

Contribuições: A distinção entre mecanismos de empoderamento e seus efeitos sobre a participação contribui para a literatura de marketing de serviços, que pode considerar efeitos distintos em modelos que analisam o desempenho de serviços. $\mathrm{O}$ artigo discute que o impacto do empoderamento do cliente na participação segue uma curva no formato de U-invertido.

Relevância / Originalidade: O mecanismo de empoderamento-para-ação pode contribuir para uma redução no risco de co-destruição de valor, já que os clientes estarão mais preparados para assumir suas funções.

Implicações gerenciais e sociais: As organizações podem melhor compreender os efeitos das estratégias escolhidas quando buscam promover o empoderamento de clientes; e políticas públicas podem se beneficiar de maior compreensão dos mecanismos que influenciam as intenções comportamentais dos clientes em relação às instituições, pois clientes mais capazes de tomar decisões são menos vulneráveis.

Palavras-chave: Cocriação se Valor. Lógica Dominante de Serviço. Empoderamento do Cliente. Participação do Cliente. Serviços Altamente Relacionais.

Patricia Silva Monteiro Boaventura ${ }^{1}$ Eliane Pereira Zamith Brito ${ }^{2}$

\footnotetext{
${ }^{1}$ Doutoranda em Administração de Empresas pela Escola de Administração de Empresas de São Paulo da Fundação Getúlio Vargas- EAESP/FGV. São Paulo, Brasil. E-mail: patboaventura@gmail.com

${ }^{2}$ Doutora em Administração pela University of Manchester, Inglaterra. Professora da Escola de Administração de Empresas de São Paulo da Fundação Getúlio Vargas - EAESP/FGV. São Paulo, Brasil. E-mail: eliane.brito@fgv.br
} 


\section{INTRODUCTION}

Customer participation can be defined as the degree to which a customer is involved in producing and delivering a service (Bitner, Faranda, Hubbert, \& Zeithaml, 1997). Although participation is intrinsic to all service contexts (Czepiel, 1990), as customers participate in a highly relational service, that is, over relatively long and intense period of contact with a service provider, outcomes emerge from collaboration between providers and customers (Dong, Evans \& Zou, 2008; Yim, Tse \& Chan, 2008). Consequently, how providers involve their customers in service experiences is key for value cocreation, which can be achieved when customers are more active in the process (Feste \& Anderson, 1995; Gronroos, 2012, Prahalad \& Ramaswamy, 2000).

Customer participation has been studied over the decades with a focus on ways to increase firm productivity (Bendapudi \& Leone, 2003; Bowers, Martin \& Luker, 1990; Fitzsimmons, 1985; Mills, Chase \& Marguiles, 1983; Mills \& Moberg, 1982; Song \& Adams, 1993); however, market relationships have changed over the years, and customers' competences, willingness to learn and abilities to actively engage have become relevant to companies' competitive advantages and customer satisfaction (Prahalad \& Ramaswamy, 2000). Changes have also occurred in how customers evaluate services and in their behavioral attitudes toward services, which are affected by relationships with providers (Parish \& Holloway 2010). A marketing orientation based on service-dominant logic (SDL) considers that value is co-created throughout the relationship between customers and providers and is not transferred from providers to customers in the moment of exchange (Vargo \& Lusch, 2004). The foundational premises of SDL imply that consumers are always contributing to value co-creation (Vargo \& Lusch, 2004, 2008); however, studies show that they may not always serve as active participants in this process (Greer, 2015).

This study shows that customer empowerment can serve as a tool to service providers seeking success in this new marketplace. However, the concept must be appropriately defined and adopted by organizations. Empowerment can refer to an increase in consumer control through the delivery of several choice opportunities or the development of an intrinsic motivation to become competent and autonomous in developing a task (Deci \& Ryan, 2008; Wolf, Albinsson \& Becker, 2015). Empowerment adoption can involve a complex reorganization of company activities so that they are successful and coherent with value propositions; otherwise, related strategies can be compromised (Gronroos, 2012; Echeverri \& Skalen,
2011). Service providers that offer opportunities to customers to move from the audience to the stage turn customers into competent partners who can impact processes and outcomes. Under these conditions, the company together with the customer co-create personalized experiences, and the company can achieve a competitive advantage (Prahalad \& Ramaswamy, 2000; Prahalad \& Ramaswamy, 2004, Thomas \& Velthouse, 1990).

Customer empowerment can be used as a reliable tool by managers striving for the co-creation of valuable experiences in a competitive market, as it can be used as a mechanism to enhance customer participation and to subsequently affect service evaluations and behavioral intentions (Czepiel, 1990; Feste \& Anderson, 1995; Gronroos, 2012); thus, it is very relevant to investigate these relationships.

The primary goal of this study is to analyze the literature on customer participation and empowerment and to present a framework that explores the effects of these constructs on service evaluations and behavioral intentions in regard to highly relational services. As highly relational services are so heavily dependent on customer participation, it is relevant to understand how organizations can turn mandatory participation into more productive interactions (Dong \& Sivakumar, 2017). This conceptual article contributes to the service marketing literature by advancing understanding of constructs definitions and related relationships, especially between empowerment and customer participation.

The paper is organized as follows. First, in the theoretical background section, fundamental constructs are defined followed by a presentation of relationships between them. The paper then proposes a framework for better evaluating how customer empowerment can leverage participation from a mandatory to a voluntary position so that it has a positive influence on service evaluations and behavioral intentions. Contributions made to theory, public policy, and managerial practices and avenues for future research are presented in the last section.

\section{THEORETICAL BACKGROUND}

This section presents a review of literature on customer participation and customer empowerment to set the groundwork for a framework that contributes to an understanding of how organizations can leverage customer participation effects on behavioral intentions. 


\section{Customer Participation}

Participation can also be defined as coproduction, which refers to interactions expected from customers in service encounters whereby customers must participate at some level (Yen, Gwinner and $\mathrm{Su}, 2004)$. Customer participation can occur at varying magnitudes, and levels of customer participation required for a service experience vary across services (Bitner et al., 1997; Bowen, 1990; Dabholkar, 1990). In some cases, customers play essential production roles that, when not fulfilled, affect the nature of service outcomes; all forms of education, training and health maintenance fit this profile (Bitner et al., 1997), and they are referred to as highly relational services. Participation in highly relational services can be viewed as a co-productive point of interaction between customers and providers whereby customer participation may be regarded as mandatory and essential to service delivery (Dong \& Sivakumar, 2017).

Bendapudi and Leone (2003) presented a summarized historical review of the literature on customer participation, illustrating the evolution of this concept in the market. The present study complements Bendapudi and Leone's (2003) analysis by applying more recent articles on customer participation and empowerment to clarify concept definitions, mechanisms of adoption and benefits to organizations and customers.

The investigated literature shows that customer participation has evolved from a point at which customers could customize certain products and services or cooperate with companies to increase productivity levels to a buyer-centric model wherein customers play an active role in seeking to impact a company's strategies and decisions. Studies conducted in the 1980s and 1990s regarded customers as a company's partial employees and expected that companies had prepared these customers to assume certain roles in delivery or production (Fitzsimmons, 1985; Lovelock \& Young, 1979; Mills et al., 1983; Mills \& Moberg, 1982). This customer/company interaction was believed to increase customer involvement and, consequently, customer satisfaction with outcomes. Results were also expected to be positive for companies, as customer involvement typically leads to an increase in productivity and higher profits. More knowledgeable customers were considered to be capable of increasing the quality of interactions, becoming more involved, reducing costs and improving their levels of satisfaction (Bowers et al., 1990; Kelley, Donnelly, and Skinner, 1990). Training customers to use service innovations, acquire knowledge on processes and use service responsibly has been mentioned by some researchers as crucial to the success of implementations and consequent increases in productivity (Bowers et al., 1990; Lovelock \& Young, 1979; Mills \& Moberg, 1982; Fitzsimmons, 1985).

Dominant in the 1990 s, relationship marketing allowed providers to become more knowledgeable of customers' needs, in turn facilitating customization; however, the organization's primary focus remained the provision of services. An emphasis was placed on training customers to contribute to the process with inputs rather than on empowering them to make choices on their own regarding services and potentially having an impact on strategic decisions.

Nevertheless, customers and thus market relationships have changed over the decades, and customer participation has acquired a social dimension because customers are no longer prepared to accept experiences developed by companies alone. Rather, they wish to shape these experiences themselves while also relying on experts and other customers (Prahalad \& Ramaswamy, 2000). In the early 2000s, companies faced a shift from a company-centered perspective to a perspective focused on the co-development of personalized experiences. Companies aiming to differentiate their offers adopted a buyer-centric model wherein customers needed to not only participate but also feel active in the production process so that customer experiences could achieve higher levels of value through co-creation (Prahalad \& Ramaswamy, 2004). Thus, the role of companies changed, and they now face the challenge of offering value propositions and of co-creating valuable experiences with customers through the exchange of information and experiences (Echeverri \& Skalen, 2011; Grönroos, 2011; Vargo \& Lusch, 2008). Companies must now be prepared to have customers participate more actively and influence their strategies.

Based on this new logic, the SDL, customers' skills, competence levels and culture play a fundamental role, and interactions between customers and service providers throughout this process become more important than the transactions themselves (Vargo \& Luch, 2004). Customer knowledge development aims to promote opportunities for customers to adopt a more active and participatory role in the delivery of service provisions (Bendapudi \& Leone, 2003; Firat \& Venkatesh, 1993; Lusch \& Vargo, 2006; Vargo \& Lusch, 2017). Cooperation and customer education in turn became extremely central to the success of an outcome achieved through active customer participation (Prahalad \& Ramaswamy, 2000, Grönroos 2011). Concepts such as co-creation and customer empowerment were more frequently used in the marketing literature (Prahalad \& Ramaswamy, 2000) and not without discussing the benefits of such proactive customer strategies. 
Some recent studies have raised questions related to possibilities of double customer exploitation occurring in co-production activities and the occurrence of the co-destruction of value, an outcome that should not be ignored during interactions (Chan, Yim \& Lam, 2010; Echeverri \& Skalen, 2011; Gronroos, 2012; Maynard, Gilson, \& Mathieu, 2012). Thus, it seems that customer empowerment impacts on service effectiveness follow an inverted-U curve shape, see Figure 1. Such studies highlight relevant issues in reinforcing the fact that customer empowerment can generate an enhanced sense of satisfaction with outcomes (Wathieu et al., 2002) though it needs to be adequately designed and applied. Managers should speculate on potential results, on their effects and ways to manage them to be successful in co-creating value with participatory and empowered customers.

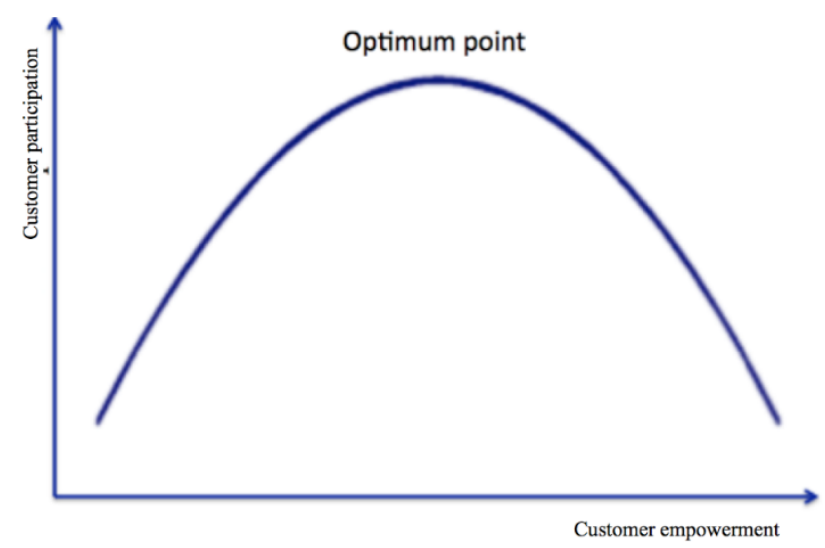

Figure 1 - The Optimum Point of Empowerment Source: developed by the authors

Customer participation discussions have recently evolved, and the construct has been defined in various forms: mandatory - activities that can only be performed by customers and that are essential for service delivery; replaceable - customer activities that are essential to service provisions but that can also be performed by the service provider; and voluntary - activities that are not essential for service delivery but that are conducted at a customer's discretion to improve his or her service experiences (Dong \& Sivakumar, 2017). We believe that the distinction between mandatory and voluntary participation (see Figure 2) can facilitate the understanding of the role of customers in value cocreation, as customers who participate beyond minimal levels of expected effort are actively involved in the co-creation of a unique experience (Dong \& Sivakumar, 2017; Vargo \& Lusch, 2004).

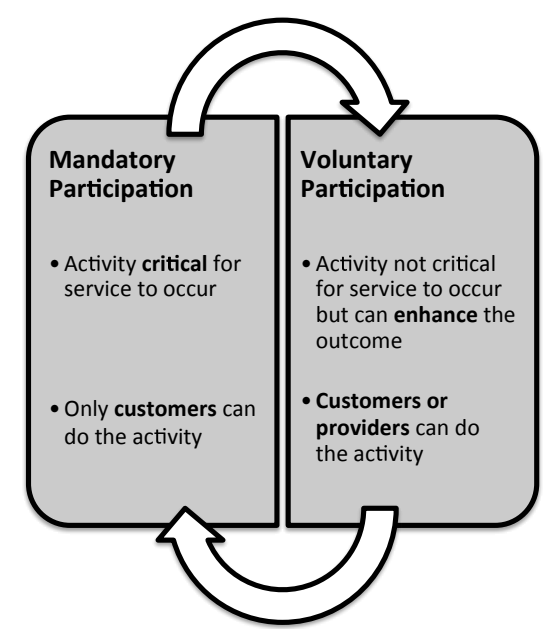

Figure 2 - Distinctions between Mandatory and Voluntary Participation Source: adapted from Dong and Sivakumar (2017) 
Within this context, empowerment appears in the marketing literature as a mechanism for enabling customers to be more active in this process. There are different levels and facets of empowerment that should be considered depending on the type of industry considered (Bachouche \& Sabri, 2018) when aiming to limit chances of value co-destruction (Echeverri \& Skalen, 2011).

\section{Customer Empowerment}

Empowerment can be applied to organizations, communities and social policies (Zimmerman \& Rappaport, 1988) and is experienced in the following three different ways: empowermentto-control, empowerment-to-resist being controlled by others and empowerment-to-act (Bachouche \& Sabri, 2018 Wolf et al., 2015). From a marketing perspective, customer empowerment has been studied as a mechanism that offers customers more control over experiences, that boosts customer confidence and ownership and that consequently increases satisfaction and encourages a willingness to pay (Fuchs, Prandelli and Schereier, 2010; Pranic and Roehl, 2012; Prentice, Han and Li, 2016; Wathieu et al., 2002). Empowerment-to-resist being controlled is similar to empowerment-to-control, but the former is used to address power imbalances between social classes or genders, while the latter is used in consumer relationships with service providers referring to choice opportunities, determining the relational nature of the construct (Bachouche \& Sabri, 2018 Fuchs et al., 2010; Wolf, et al., 2015). Empowerment-to-act refers to psychological empowerment and is an intrapersonal construct referring to conditions in which customers feel competent and have the information needed to make choices and to impact processes (Pranic \&
Roehl, 2012; Prentice et al., 2016; Thomas \& Velthouse; 1990).

Psychological empowerment can be described as the connection between a sense of personal competence, a desire for action, and a willingness to take action in the public domain (Zimmerman \& Rappaport, 1988); it "includes beliefs that goals can be achieved, awareness about resources and factors that hinder or enhance one's efforts to achieve those goals, and efforts to fulfill the goals" (Zimmerman, 1995). The definition of psychological empowerment corresponds to Conger and Kanungo's (1988) use of the construct as a motivational construct. The control delegation (empowerment-to-control) view merely considers the transfer of power; this view was restricted to the behavior of superiors/organizations delegating power and did not assume that subordinates/customers must be allowed to successfully advance a task (Lee \& Koh, 2001).

Thomas and Velthouse (1990); Lee and Koh (2001); Kirkman and Rosen (1999); and Maynard, Gilson and Mathieu (2012) extended Conger and Kanungo's work on psychological empowerment and used definitions offered by Zimmerman (1990) and Seibert, Wang and Courtright (2011); they propose that empowerment is a construct composed of four dimensions: impact or individual effects on outcomes; selfefficacy/competence or a belief that the use of personal skills will lead to successful outcomes; meaningfulness or feeling that a task has particular value; and choice/self-determination or a sense of autonomy in selecting and initiating an activity (Thomas \& Velthouse, 1990; Wolf et al., 2015). Figure 3 presents the main differences between empowerment-to-control and empowerment-to-act. 


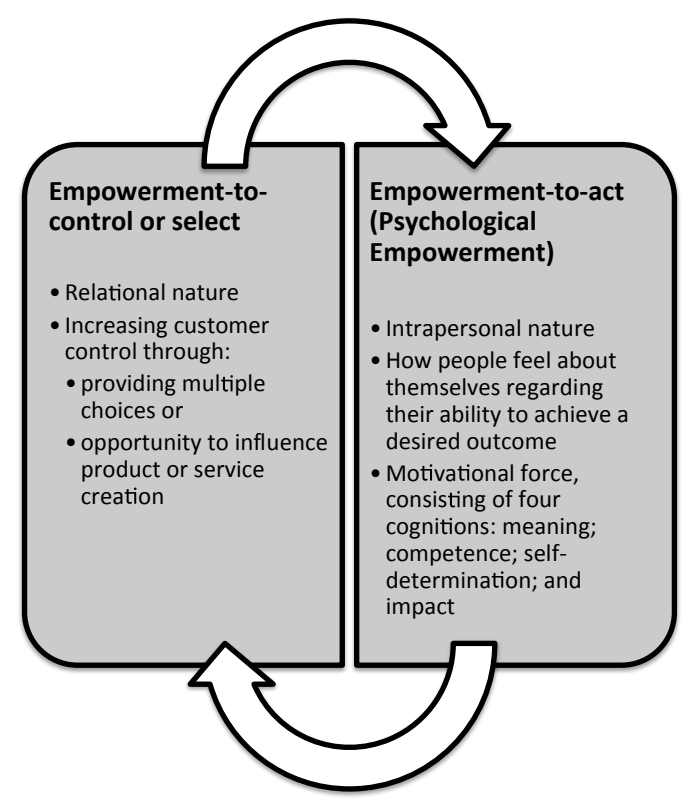

Figure 3 - Characteristics of Empowerment-to-control and Empowerment-to-act

Source: based on Bachouche and Sabri (2010); and Wolf, Albinsson and Becker (2015)

Despite the increased need to comprehend customer empowerment such that companies can differentiate and co-create more value during the customer experience, there has been a lack of service marketing discussions on customer empowerment definitions. On the other hand, the relevant medical literature on patient empowerment (Ouschan, Sweeney \& Johnson, 2000) addresses customer empowerment in a specific context that enhances the construct's definition and that affects discussions. Patient empowerment clearly serves as a suitable starting point for learning about customer empowerment, as it is not only relevant to marketers who, in a position to help doctors, empower their patients, but it also offers a perspective on how professional service providers of highly relational services (i.e., banking, tourism, education and other services) involving complex or long-term relationships can empower customers in service encounters (Ouschan et al., 2000).

The healthcare industry offers examples of how customer participation occurs in correspondence with customer empowerment-to-act. Customers of the healthcare system are currently characterized as active actors in the network, similar to health care providers. All participants are considered to exercise their control, power, and influence over the web, and they base their activities on the direct or indirect control of resources, with control also being a function of knowledge (Hult \& Lukas, 1995). However, this relationship is not restricted to an increase in customer power and control; in healthcare services, to obtain quality, value, and performance levels acceptable to all actors involved, it is essential that patients feel competent enough to participate in decision-making processes (Hult \& Lukas, 1995). Customers may develop the skills, attitudes, and self-awareness needed to efficiently assume responsibility over their health-related decisions (Feste \& Anderson, 1995); both patients and doctors share a responsibility for treatments and outcomes, and patient education is essential to the process and is crucial to the realization of positive results. In a traditional health care program based on compliance-oriented training, patients receive information on how to apply prescribed recommendations, and their participation is mandatory (Dong \& Sivakumar, 2017). Conversely, according to the empowerment approach, patients are prepared to act as equal and autonomous members of their healthcare teams; they learn enough about their disease and achieve selfawareness of their health values, needs, and goals. They participate in a voluntary manner and beyond what is expected (Dong \& Sivakumar, 2017). Recommendations are tailored to the patient's life rather than the reverse (Feste \& Anderson, 1995).

The described studies clarify the importance of understanding differences between empowerment concepts (empowerment-to-control and empowerment-to-act) such that organizations can adopt successful strategies for working with their customers. Highly relational services that aim for more active and voluntary participation may focus on investigating how customers can become empowered-to-act.

From this more precise definition of customer participation and empowerment, we can 
now discuss the relationship between these variables and service evaluations and behavioral intentions of a highly relational services context. Table 1 shows an updated version of the chronological review offered by Bendapudi and Leone (2003).

Table 1 - A Chronological Review of the Literature on Customer Participation

\begin{tabular}{|c|c|c|c|}
\hline Author & Focus & $\begin{array}{l}\text { Nature of } \\
\text { the study }\end{array}$ & Findings and conclusions \\
\hline $\begin{array}{l}\text { Lovelock and } \\
\text { Young (1979) }\end{array}$ & $\begin{array}{l}\text { Consequences of customer } \\
\text { participation for the } \\
\text { production of services }\end{array}$ & Conceptual & Customers can be a source of productivity gains. \\
\hline $\begin{array}{l}\text { Mills and } \\
\text { Moberg } \\
(1982)\end{array}$ & $\begin{array}{l}\text { Organizational } \\
\text { technologies needed to } \\
\text { manage the services sector } \\
\text { as opposed to the goods } \\
\text { sector }\end{array}$ & Conceptual & $\begin{array}{l}\text { One key difference between the two industries is the } \\
\text { customer's/client's role in the production process. The } \\
\text { customer can increase productivity in services and must } \\
\text { be prepared. }\end{array}$ \\
\hline $\begin{array}{l}\text { Mills, Chase } \\
\text { and Marguiles } \\
\quad(1983)\end{array}$ & $\begin{array}{l}\text { Managing the } \\
\text { customer/client as a partial } \\
\text { employee to increase } \\
\text { system productivity }\end{array}$ & Conceptual & $\begin{array}{l}\text { More customer involvement in the production process } \\
\text { can spur productivity gains. Customers' inputs must be } \\
\text { monitored and assessed the same way as regular } \\
\text { employees' inputs are. }\end{array}$ \\
\hline $\begin{array}{l}\text { Fitzsimmons } \\
\qquad(1985)\end{array}$ & $\begin{array}{l}\text { The consequences of } \\
\text { customer participation for } \\
\text { service sector productivity }\end{array}$ & Conceptual & $\begin{array}{l}\text { Customer participation may yield higher levels of service } \\
\text { sector productivity. Technological innovations depend } \\
\text { on customer acceptance and on customer training on } \\
\text { using them. }\end{array}$ \\
\hline Czepiel (1990) & \begin{tabular}{|l|l|}
$\begin{array}{l}\text { The nature of service } \\
\text { encounters }\end{array}$ & \\
\end{tabular} & Conceptual & $\begin{array}{l}\text { Customer participation in the production process may } \\
\text { affect customer satisfaction. }\end{array}$ \\
\hline Bowen (1990) & $\begin{array}{l}\text { The taxonomy of services } \\
\text { based on customer } \\
\text { participation }\end{array}$ & Empirical & $\begin{array}{l}\text { Participation can be used a meaningful way to describe } \\
\text { services. It may be possible to segment customers based } \\
\text { on their willingness to participate in service creation. }\end{array}$ \\
\hline $\begin{array}{l}\text { Bowers, } \\
\text { Martin, and } \\
\text { Luker (1990) }\end{array}$ & $\begin{array}{l}\text { Treating employees like } \\
\text { customers and treating } \\
\text { customers like employees }\end{array}$ & Conceptual & $\begin{array}{l}\text { Treating employees as customers through internal } \\
\text { marketing and treating customers as employees through } \\
\text { training and reward systems enhances productivity. }\end{array}$ \\
\hline $\begin{array}{l}\text { Kelley, } \\
\text { Donnelly, and } \\
\text { Skinner } \\
\text { (1990) }\end{array}$ & $\begin{array}{l}\text { Managing customer roles } \\
\text { when customers participate } \\
\text { in service production and } \\
\text { delivery }\end{array}$ & Conceptual & $\begin{array}{l}\text { Customers may be managed as partial employees when } \\
\text { participating in service production and delivery by } \\
\text { focusing on customers' technical and functional quality } \\
\text { inputs to the process. Customer socialization is used to } \\
\text { manage the behaviors of customers. }\end{array}$ \\
\hline $\begin{array}{l}\text { Dabholkar } \\
\quad(1990)\end{array}$ & $\begin{array}{l}\text { Customer participation that } \\
\text { enhances service quality } \\
\text { perceptions }\end{array}$ & Conceptual & Customer participation may influence perception quality. \\
\hline $\begin{array}{l}\text { Firat and } \\
\text { Venkatesh } \\
(1993)\end{array}$ & $\begin{array}{l}\text { Arguments for the reversal } \\
\text { of consumption and } \\
\text { production roles }\end{array}$ & Conceptual & $\begin{array}{l}\text { Of postmodern conditions discussed is the reversal of } \\
\text { consumption and production as customers take on more } \\
\text { active roles in production. }\end{array}$ \\
\hline $\begin{array}{c}\text { Song and } \\
\text { Adams (1993) }\end{array}$ & $\begin{array}{l}\text { Customer participation in } \\
\text { production and delivery as } \\
\text { an opportunity for } \\
\text { differentiation }\end{array}$ & Conceptual & $\begin{array}{l}\text { Customer participation should not always be examined } \\
\text { as a merely cost-minimization problem. Instead, firms } \\
\text { can investigate means of differentiating their market } \\
\text { offerings by heightening or lessening customer } \\
\text { participations in the production and delivery of products. }\end{array}$ \\
\hline $\begin{array}{l}\text { Firat and } \\
\text { Venkatesh } \\
(1995)\end{array}$ & \begin{tabular}{|lr} 
Distinguishes & between \\
customers' views & on \\
modernism & and \\
postmodernism &
\end{tabular} & Conceptual & $\begin{array}{l}\text { A modernist perspective confines the customer by } \\
\text { arguing for the "privileging" of production over } \\
\text { consumption. Postmodernism offers a basis for } \\
\text { understanding a more significant customer role in } \\
\text { production and consumption. }\end{array}$ \\
\hline $\begin{array}{l}\text { Firat, } \\
\text { Dholakia, and } \\
\text { Venkatesh, } \\
(1995)\end{array}$ & $\begin{array}{l}\text { Presents a postmodern } \\
\text { view of customers as } \\
\text { customizers and producers }\end{array}$ & Conceptual & $\begin{array}{l}\text { As customers have become customizers, marketing } \\
\text { organizations' offerings will increasingly become } \\
\text { processes rather than finished products. Customers who }\end{array}$ \\
\hline
\end{tabular}




\begin{tabular}{|c|c|c|c|}
\hline & & & $\begin{array}{l}\text { are integrated into production systems will need to be } \\
\text { conceptualized as producers. }\end{array}$ \\
\hline $\begin{array}{c}\text { Hult and } \\
\text { Lukas (1995) }\end{array}$ & $\begin{array}{l}\text { Customer participation in } \\
\text { healthcare }\end{array}$ & Conceptual & $\begin{array}{l}\text { Classifying healthcare tasks regarding customer } \\
\text { participation and complexity has significant implications } \\
\text { for service marketing. }\end{array}$ \\
\hline $\begin{array}{l}\text { Lengnick-Hall } \\
\text { (1996) }\end{array}$ & $\begin{array}{l}\text { Customer contributions to } \\
\text { quality levels }\end{array}$ & Conceptual & $\begin{array}{l}\text { Customers influence quality levels through their roles as } \\
\text { resources, co-producers, buyers, users, and products. } \\
\text { Garnering customer talent in these roles can yield } \\
\text { competitive advantages. }\end{array}$ \\
\hline $\begin{array}{c}\text { Raaij and } \\
\text { Pruyn (1998) }\end{array}$ & $\begin{array}{l}\text { Customer control and its } \\
\text { impact on judgments of } \\
\text { service validity and } \\
\text { reliability }\end{array}$ & Conceptual & $\begin{array}{l}\text { Customers may feel that they have more or less control } \\
\text { over three stages of the service relationship: input, } \\
\text { throughput, and output. The higher a customer's sense of } \\
\text { control, the more he or she will feel responsible for and } \\
\text { satisfied with a service. }\end{array}$ \\
\hline $\begin{array}{l}\text { Prahalad and } \\
\text { Ramaswamy } \\
\quad(2000)\end{array}$ & $\begin{array}{l}\text { Coopting } \\
\text { competence }\end{array}$ & Conceptual & $\begin{array}{l}\text { Customers have evolved from a passive audience to } \\
\text { active co-creators of experience. Customer competence } \\
\text { can leverage companies' competitive advantages. }\end{array}$ \\
\hline $\begin{array}{l}\text { Wind and } \\
\text { Rangaswamy } \\
\text { (2001) }\end{array}$ & $\begin{array}{l}\text { Customerization: The next } \\
\text { revolution in mass } \\
\text { customization }\end{array}$ & Conceptual & $\begin{array}{l}\text { In the digital marketplace, customers are becoming } \\
\text { active participants in product development, purchasing, } \\
\text { and consumption. Firms must become customer-centric } \\
\text { and adopt "customerization" to add value. }\end{array}$ \\
\hline $\begin{array}{l}\text { Lee and Koh, } \\
\qquad(2001)\end{array}$ & $\begin{array}{l}\text { Defining empowerment } \\
\text { and distinguishing it from } \\
\text { similar terms }\end{array}$ & Conceptual & $\begin{array}{l}\text { A definition of empowerment must integrate aspects of } \\
\text { both behavior and perception. This can be defined as the } \\
\text { psychological state of a subject based on the four } \\
\text { dimensions of meaningfulness, competence, self- } \\
\text { determination and impact, which are affected by } \\
\text { empowering supervisor behaviors. }\end{array}$ \\
\hline $\begin{array}{l}\text { Wathieu et al. } \\
\text { (2002) }\end{array}$ & $\begin{array}{l}\text { Outlines an agenda for } \\
\text { future research on } \\
\text { customer empowerment }\end{array}$ & Conceptual & $\begin{array}{l}\text { Customers will not always view an increase in control as } \\
\text { a benefit. A stronger sense of control may not lead to a } \\
\text { greater sense of empowerment, and a greater sense of } \\
\text { empowerment may lead to a stronger awareness of costs } \\
\text { to customers. }\end{array}$ \\
\hline $\begin{array}{c}\text { Cova and } \\
\text { Dalli (2009) }\end{array}$ & $\begin{array}{l}\text { Emphasizes the } \\
\text { sociocultural dimension of } \\
\text { customer participation }\end{array}$ & Conceptual & $\begin{array}{l}\text { Customers work and are active in the value creation } \\
\text { process. Customers work to feel satisfied and socially } \\
\text { recognized, and they do not necessarily receive } \\
\text { economic benefits. }\end{array}$ \\
\hline $\begin{array}{l}\text { Chan, Yim } \\
\text { and Lam } \\
(2010)\end{array}$ & $\begin{array}{l}\text { Customer participation in } \\
\text { value creation and } \\
\text { satisfaction for customers } \\
\text { and employees in } \\
\text { professional financial } \\
\text { services }\end{array}$ & Empirical & $\begin{array}{l}\text { Customer participation increases economic and } \\
\text { relational value, but it also leads to a shift in power, } \\
\text { increasing employee stress levels, moderating effects of } \\
\text { cultural value on the relationship between customer } \\
\text { participation and value creation. }\end{array}$ \\
\hline $\begin{array}{l}\text { Fuchs, } \\
\text { Prandelli and } \\
\text { Schereier } \\
(2010) \\
\end{array}$ & $\begin{array}{l}\text { Use of the Internet to } \\
\text { integrate customers more } \\
\text { actively into new product } \\
\text { development processes }\end{array}$ & Empirical & $\begin{array}{l}\text { Results show that customers who are empowered to } \\
\text { select products to be marketed show more demand for } \\
\text { underlying products even though they are of identical } \\
\text { quality in objective terms. }\end{array}$ \\
\hline $\begin{array}{l}\text { Parish and } \\
\text { Holloway } \\
\text { (2010) }\end{array}$ & $\begin{array}{l}\text { Understanding customer } \\
\text { relationship proneness and } \\
\text { its effects on customer } \\
\text { relationship management }\end{array}$ & Empirical & $\begin{array}{l}\text { This paper focuses on furthering understanding of how } \\
\text { consumer relationship proneness (CRP) is linked to trust } \\
\text { and other relationship outcomes (e.g., customer sharing } \\
\text { and adherence). It also examines how the nature of a } \\
\text { service exchange (transactional versus relational) affects } \\
\text { the association between CRP and commitment and trust. }\end{array}$ \\
\hline $\begin{array}{l}\text { Echeverri and } \\
\text { Skalen (2011) }\end{array}$ & $\begin{array}{l}\text { Value formation is not only } \\
\text { associated with value co- } \\
\text { creation but also with value } \\
\text { co-destruction }\end{array}$ & Empirical & $\begin{array}{l}\text { This qualitative empirical study examines the practice of } \\
\text { provider/customer interactions from the employee's } \\
\text { perspective. Practices leading to the co-creation and co- } \\
\text { destruction of value when interactions occur are } \\
\text { identified. Value is bidirectional. }\end{array}$ \\
\hline
\end{tabular}




\begin{tabular}{|c|c|c|c|}
\hline $\begin{array}{c}\text { Pranic and } \\
\text { Roehl (2012) }\end{array}$ & $\begin{array}{l}\text { Customers' views of } \\
\text { empowerment in the } \\
\text { management of service } \\
\text { recovery encounters }\end{array}$ & Conceptual & $\begin{array}{l}\text { Empowerment in a service recovery context denotes that } \\
\text { customers have information, competence, and influence } \\
\text { over the recovery process. }\end{array}$ \\
\hline $\begin{array}{l}\text { Wolf, } \\
\text { Albinsson and } \\
\text { Becker (2015) }\end{array}$ & $\begin{array}{l}\text { Female involvement in do- } \\
\text { it-yourself behaviors }\end{array}$ & Empirical & $\begin{array}{l}\text { For the context of organizational research, the article } \\
\text { identifies three interrelated but distinct empowerment } \\
\text { mechanisms: the power to control, the power to act, and } \\
\text { the power to resist being controlled by others. }\end{array}$ \\
\hline $\begin{array}{l}\text { Prentice, Han } \\
\text { and Li (2016) }\end{array}$ & $\begin{array}{l}\text { Scaling development to } \\
\text { measure customers' } \\
\text { psychological } \\
\text { empowerment }\end{array}$ & Empirical & $\begin{array}{l}\text { The study shows that customers view empowerment as } \\
\text { involving offering more product options (service } \\
\text { choices) and that it is provided through two-way } \\
\text { communication channels to facilitate information } \\
\text { attainment so they can share consumption experiences } \\
\text { (information attainment) and affect the service delivery } \\
\text { process (impact). }\end{array}$ \\
\hline $\begin{array}{l}\text { Dong and } \\
\text { Sivakumar } \\
\quad(2017)\end{array}$ & $\begin{array}{l}\text { Classifies } \\
\text { participation into three } \\
\text { categories: } \quad \text { mandatory, } \\
\text { replaceable, and voluntary }\end{array}$ & Conceptual & $\begin{array}{l}\text { Each form of customer participation (mandatory, } \\
\text { replaceable and voluntary) can occur at varying levels } \\
\text { (e.g., low vs. high). Mandatory participation refers to } \\
\text { activities/resources that can only be performed/provided } \\
\text { by customers and that are essential for service delivery; } \\
\text { replaceable CP relates to customer activities/resources } \\
\text { that are essential for service providers but that can also } \\
\text { be performed by a service provider, and voluntary CP } \\
\text { refers to activities and resources that are not essential for } \\
\text { service delivery but that are delivered at a customer's } \\
\text { discretion to improve his or her service experiences. }\end{array}$ \\
\hline $\begin{array}{l}\text { Bachouche } \\
\text { and Sabri } \\
(2018)\end{array}$ & $\begin{array}{l}\text { Literature review } \\
\text { "empowerment" }\end{array}$ & Conceptual & $\begin{array}{l}\text { The marketing literature related to consumer } \\
\text { empowerment can be classified according to the three } \\
\text { facets of empowerment: the delegation of power by local } \\
\text { authorities or companies to consumers; the acquisition of } \\
\text { power from the consumer's perspective, which focuses } \\
\text { on resistance to market structures; and empowerment as } \\
\text { a subjective state referred to as "psychological } \\
\text { empowerment" and referring to the consumer's "sense of } \\
\text { empowerment" as related to an extension of resources } \\
\text { and to easier access to information through Web 2.0. }\end{array}$ \\
\hline
\end{tabular}

Source: developed by the authors based on Bendapudi and Leone (2003) and other studies

\section{PROPOSED FRAMEWORK AND DISCUSSION}

\section{Effect of Participation on Service Evaluation, and Behavioral Intention}

Customer participation affects perception of service quality (Cheung \& To, 2011), satisfaction (Bendapudi \& Leone, 2003) and even new product value (Fang, Palmatier \& Evans, 2008). Some authors defend the notion that an increase in customer involvement in service production and delivery leads to higher levels of perceived value and satisfaction (Cova \& Dalli, 2009). Experiments have been conducted to measure customer participation effects on satisfaction. For example, Bendapudi and Leone (2003) showed that customer participation affects perceived quality and satisfaction. Through an empirical study of high credence services Chan et al. (2010) proved that customer participation increases economic and relational value, consequently improving customer satisfaction (Chan et al., 2010; Cova \& Dalli, 2009). Cronin, Brady, and Hult (2000) also found a combined effect of service quality (SQ), service value (SV), and customer satisfaction (CS) on behavioral intentions to recommend or repurchase a service. See Figure 4 for an illustration of the effects discussed. 


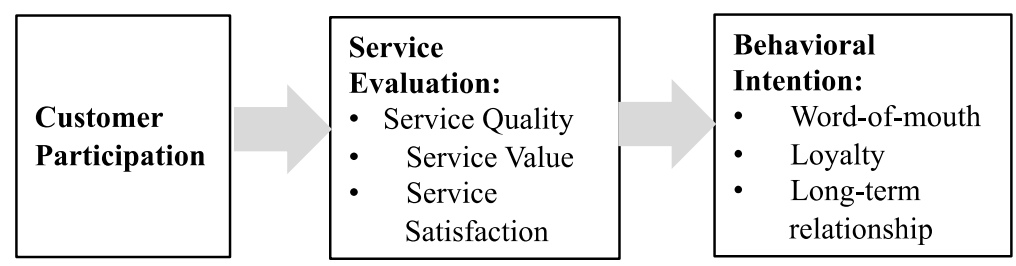

Figure 4 - Customer Participation Affecting Service Evaluation and Behavioral Intentions Source: developed by the authors

Given that customer participation can vary from more passive to more active, more committed individuals are more involved as partial employees and should consequently be more efficient. Additionally, involvement and identification with one's role can affect one's expectations and levels of satisfaction; more involved customers are more identified with their partial employee role and will, consequently, be more satisfied (Kelley et al., 1990). We then propose that when customers engage in voluntary participation beyond what is expected, they are more actively involved in the process and, consequently, perceive more value, are more satisfied and develop a more positive view of the provider.

Thus, how can organizations offer opportunities for customers to feel motivated to participate more actively and in turn positively leverage effects of participation on service evaluations and behavioral intentions? We assume that organizations may offer opportunities for customers to be enthusiastic to participate.

Customers with more control over specification and realization (power-to-control) perceive themselves as co-producers and more responsible for outcomes, further enhancing their involvement in the process (Raaij \& Pruyn, 1998). In highly relational services, customer participation is intrinsic-mandatory-to the given context, but customers exhibiting power-to-control tendencies may engage in a certain level of voluntary participation, achieving higher service evaluations and more positive behavioral intentions towards the provider.

The current study proposes that customer participation affects service evaluations differently depending on the type and level of participation involved (only inputs (mandatory) or more active participation in the process (voluntary)); further, participation can shift from mandatory to voluntary when opportunities for customers to become empowered are offered by organizations.

\section{Empowerment Leveraging Mechanism}

Brambilla and Damacena (2012) developed a conceptual framework in which the co-creation of value and student participation in an educational environment occurs based on students' (customers') intrinsic motivations, leading to effects of perceived quality, performance and satisfaction and culminating in student loyalty and retention. This study proposed that when the provider creates conditions extending beyond choice opportunities (empowerment-to-control) and helps the customer become competent and to obtain enough information to make meaningful choices and to impact the process, the customer feels empowered-to-act and intrinsically motivated to engage in more active and voluntary participation. Then, customer empowerment-to-act positively leverages the relationship between customer participation and service evaluation, as according to this scenario customers are more prepared to effectively contribute to the process.

Considering these insights we contribute to the literature on customer participation and on its effects by proposing a model based on theoretical discussions that apply customer empowerment as a construct that can make a relevant difference in such relations based on how organizations develop strategies that promote customers' empowermentto-control or empowerment-to-act. This discussion is illustrated in Figure 5. 


\begin{tabular}{|c|c|c|c|}
\hline $\begin{array}{l}\text { Empowerment Strategy } \\
\text { Empowerment-to- } \\
\text { control or select (lower } \\
\text { effect on the outcome) } \\
\text { - Empowerment-to-act } \\
\text { (higher effect on the }\end{array}$ & $\begin{array}{l}\text { Customer Participation } \\
\text { - Mandatory or minimum } \\
\text { required to service } \\
\text { occur, or } \\
\text { - Voluntary / can enhance } \\
\text { the service outcome }\end{array}$ & $\begin{array}{l}\text { Service Evaluation } \\
\text { - Service Quality } \\
\text { - Service Value } \\
\text { - Service } \\
\quad \text { Satisfaction }\end{array}$ & $\begin{array}{l}\text { Behavioral Intention } \\
\text { - Word-of-mouth } \\
\text { - } \quad \text { Loyalty } \\
\text { - } \quad \text { Long-term } \\
\quad \text { relationship }\end{array}$ \\
\hline
\end{tabular}

Figure 5 - Proposed Framework

Source: developed by the authors

In the proposed framework, a higher customer empowerment leads to a more active customer participation, but at certain level of customer empowerment, the higher customer empowerment can lead to a lower participation (Echeverri \& Skalen, 2011; Maynard et. al., 2012). Customer empowerment influences the type and level of participation involved, as empowered customers may feel more prepared and motivated to voluntarily participate by contributing beyond what is expected. While empowered-to-control customers will have a relational and extrinsic motivation to take part beyond what is expected, empowered-to-act customers will also have an intrinsic motivation to participate voluntarily, in turn leveraging effects on service evaluations and behavioral intentions (Deci \& Ryan, 2008). But, this research proposes that there is an optimal point of participation, and beyond that empowerment can even become a source of stress to customers and service providers, see Figure 1 (Maynard et. al., 2012).

\section{CONTRIBUTIONS, LIMITATIONS AND FUTURE STUDIES}

In highly relational services, customer participation is intrinsic and mandatory to the given context (Czepiel, 1990; Dong et al., 2008), and customer empowerment can significantly help leverage customer participation from mandatory inputs to an active involvement aimed toward service excellence. In contexts in which customers are more knowledgeable and are seeking more active participation, companies must be able to leverage such customer dispositions by shifting customers from the audience to the stage (Prahalad \& Ramaswamy, 2000). Organizations can offer opportunities for empowerment at different levels depending on the strategies used. Customer empowerment may be restricted to empowermentto-control, but it can also imply meaningfulness, competence, and impacts beyond choice opportunities, empowering customers to act (Bachouche \& Sabri, 2018 Wolf et al., 2015). When customers are not only prepared to participate but are also intrinsically motivated to contribute, interactions will be positively affected (Deci \& Ryan, 2008; Gronroos, 2012). This study proposes that empowered-to-act customers are intrinsically motivated to actively participate in this process and to successfully co-create valuable and personalized experiences (Deci \& Ryan, 2008; Prahalad \& Ramaswamy, 2000).

The current study academically contributes to the research on service marketing by showing that knowledge of forms of customer participation (mandatory and voluntary) and of strategies of empowerment (empowerment-to-control or empowerment-to-act) are relevant to understanding service evaluations and customers' behavioral intentions (Bachouche \& Sabri, 2018 Bendapudi \& Leone, 2003; Chan et al., 2010; Cheung \& To, 2011; Cova \& Dalli, 2009; Dong \& Sivakumar, 2017; Fang, Palmatier \& Evans, 2008; Wolf et al., 2015). This distinction between different empowerment mechanisms and their effects on how participation develops in highly relational services contributes to the literature on service marketing, which may consider distinctive effects in models explaining service performance and behavioral intentions and to organizations in clarifying the effects of chosen strategies. The study focused on furthering the discussion of forms of participation and empowerment and of how different forms of empowerment that organizations can encourage affect how participation will occur (mandatorily or voluntarily). It is the effects of this participation, which can be more passive (mandatory) or active (voluntary), that will define service evaluations and intentions of behavior.

Management practices should also be improved in consideration of customer empowerment levels, and managers should address challenges associated with managing this issue. We propose that in highly relational services contexts, organizations will benefit from offering customers opportunities to assume a more active role that is meaningful, that involves competence and awareness and that entails opportunities to make good choices and positively impact their experiences, consequently limiting the likelihood of 
adverse experiences and value co-destruction (Echeverri \& Skalen, 2011; Gronroos, 2012; Maynard et al., 2012). Empowerment opportunities have to be monitored so that co-destruction of value is avoided (Maynard et. al., 2012). The offering of choice opportunities constitutes another mechanism of empowerment promotion but in this case in relation to empowerment-to-control or to select, and the expected results are less effective than when empowerment-act is supported. However, determining which strategy of empowerment to support depends on the given service context and must be carefully evaluated by organizations aiming to promote valuable experiences. Value codestruction studies may also consider different context particularities and how empowerment mechanisms may have different effects on customers' willingness to serve as active participants.

Public policies can also benefit from a more comprehensive understanding of mechanisms influencing customers' behavioral intentions toward institutions, as customers who are more capable of taking decisions are less vulnerable (Smith \& Cooper-Martin, 1997).

Moreover, there are strategic decisions and capabilities that a company must develop such that interactive processes can successfully be developed with empowered customers. Empowered customers require internal support, as customer interactions must be managed and forged into valuable opportunities for process improvements (Gronroos, 2012). Companies will likely need to review the role of their staff, as increasing customer competence without enhancing value perceptions in other ways, which may entail organizational changes, may not be effective (Hilton, Huges \& Chalcraft, 2012). The investigation of capabilities that companies must develop internally and among their customers and other stakeholders may be investigated in the future.

This study investigates the context of highly relational services, in which interactions between customers and providers are crucial to the realization of successful outcomes (Dong et al., 2008; Yim, Tse \& Chan, 2008); and the empowerment-to-act mechanism described may contribute to a reduction in value co-destruction risk, as customers will be more prepared to assume their roles (Echeverri \& Skalen, 2011; Gronroos, 2012). The investigation of other services and contexts, such as consumer goods, may be the focus of future studies and may reveal other relevant variables that must be considered.

Further empirical investigations should be prioritized to better understand leveraging mechanisms of customer empowerment in relationships between customer participation, service evaluations, and behavioral intentions in consideration of differences between contexts, services and industries. Context specificities must be explored so that different models can be proposed and empirically tested. New variables may in turn be identified and found to be relevant as antecedents or even moderators of the proposed relationship depending on the context considered.

\section{REFERENCES}

Bachouche H. \& Sabri O. (2018) Empowerment in Marketing: Synthesis, Critical Review, and Agenda for Future Research: An Abstract. In: Rossi P., Krey N. (eds) Marketing Transformation: Marketing Practice in an Ever Changing World. AMSWMC 2017. Developments in Marketing Science: Proceedings of the Academy of Marketing Science. Springer, Cham.

Bendapudi, N. \& Leone, R.P. (2003). Psychological Implications of Customer Participation in CoProduction. Journal of Marketing, 67(1), pp.14-28.

Bitner, M.J., Faranda, W. T., Hubbert, A. R. \& Zeithaml, V. A. (1997). Customer contributions and roles in service delivery. International Journal of Service Industry Management, 8(3), pp.193-205.

Bowen, J. (1990). Development of a taxonomy of services to gain strategic marketing insights. Journal of the Academy of Marketing Science, 18(1), pp. 43-49.

Bowers, M.R., Martin, C.L. \& Luker, A. (1990). Trading Places: Employees as Customers, Customers as Employees. Journal of Services Marketing, 4(2), pp.55-69.

Brambilla, F.R. \& Damacena, C. (2012). Estudo Etnometodológico da Cocriação de Valor no Ensino Superior Privado de Administração com Base na Lógica Dominante do Serviço em Marketing. REMark-Revista Brasileira de Marketing, 11(3), pp.123-152.

Chan, K.W., Yim, C. K. \& Lam, S. S. K. (2010). Is Customer Participation in Value Creation a DoubleEdged Sword? Evidence from Professional Financial Services Across Cultures. Journal of Marketing, 74(3), pp.48-64.

Cheung, M.F.Y. \& To, W.M. (2011). Customer involvement and perceptions: The moderating role of customer co-production. Journal of Retailing and Consumer Services, 18(4), pp.271-277. 
Conger, J. A. \& Kanungo, R.N. (1988). The Empowerment Process: Integrating Theory and Practice. The Academy of Management Review, 13(3), pp.471.

Cova, B. \& Dalli, D. (2009). Working Consumers: The Next Step in Marketing Theory? Marketing Theory, 9(3), pp.315-339.

Cronin, J.J., Brady, M.K. \& Hult, G.T.M. (2000). Assessing the effects of quality, value, and customer satisfaction on consumer behavioral intentions in service environments. Journal of Retailing, 76(2), pp.193-218.

Czepiel, J. A. (1990). Service encounters and service relationships: Implications for research. Journal of Business Research, 20(1), pp.13-21.

Dabholkar, P.A. (1990). How to Improve Perceived Service Quality by Increasing Customer Participation. In: Proceedings of the 1990 Academy of Marketing Science (AMS) Annual Conference. Developments in Marketing Science: Proceedings of the Academy of Marketing Science 2015. Springer International Publishing, pp. 483-487.

Deci, E. L., \& Ryan, R. M. (2008). Selfdetermination theory: A macrotheory of human motivation, development, and health. Canadian Psychology/Psychologie canadienne, 49(3), 182185.

Dong, B., \& Sivakumar, K. (2017). Customer participation in services : domain, scope, and boundaries. Journal of the Academy of Marketing Science, 45(6), pp. 944-965.

Dong, B., Evans, K. R. \& Zou, S. (2008). The effects of customer participation in co-created service recovery. Journal of the Academy of Marketing Science, 36(1), pp. 123-137.

Echeverri, P. \& Skalen, P. (2011). Co-creation and co-destruction: A practice-theory based study of interactive value formation. Marketing Theory, 11(3), pp.351-373.

Fang, E., Palmatier, R.W. \& Evans, K.R. (2008). Influence of customer participation on creating and sharing of new product value. Journal of the Academy of Marketing Science, 36(3), pp.322-336.

Feste, C. \& Anderson, R.M. (1995).

Empowerment : from philosophy to practice. Patient Education and Counseling, (26), pp.139144.
Firat, F.A. \& Venkatesh, A. (1993). Postmodernity: the age of marketing. International Journal of Research in Marketing, 10(3), pp.227-249.

Firat, F.A. \& Venkatesh, A. (1995). Liberatory Postmodernism and Consumption the Reenchantment of Consumption. Journal of Consumer Research, 22(3), pp.239-267.

Firat, F.A., Dholakia, N. \& Venkatesh, A. (1995). Marketing in a postmodern world. European Journal of Marketing, 29(1), pp.40-56.

Fitzsimmons, J.A. (1985). Consumer Participation and Productivity in Service Operations. The Institute of Management Sciences/The University of Texas at Austin, (May-June), pp.60-67.

Fuchs, C., Prandelli \& E., Schreier, M. (2010) The Psychological Effects of Empowerment Strategies on Consumers' Product Demand. Journal of Marketing, 74(1), pp. 65-79.

Greer, D. A. (2015). Defective co-creation: Developing a typology of consumer dysfunction in professional services. European Journal of Marketing, 49(1/2), pp.238-261.

Gronroos, C. (2011). Value co-creation in service logic: A critical analysis. Marketing Theory, 11(3), pp.279-301.

Gronroos, C. (2012). Conceptualising value cocreation: A journey to the 1970s and back to the future, Journal of Marketing Management, 28(1314), pp. 1520-1534.

Hilton, T., Hughes, T. \& Chalcraft, D. (2012). Service co-creation and value realisation, Journal of Marketing Management, 28(13-14), pp. 15041519.

Hult, G.T.M. \& Lukas, B.A. (1995). Classifying health care offerings to gain strategic marketing insights. Journal of Services Marketing, 9(2), pp.36-48.

Kelley, S.W., Donnelly, J. \& Skinner, S.J. (1990). Customer Participation in Service Production and Delivery. Journal of Retailing, 66(3), pp.315-335.

Kirkman, B.L. \& Rosen, B. (1999). Beyond SelfManagement: Antecedents and consequences of team empowerment. Academy of Management Journal, 42(1), pp.58-74.

Lee, M. \& Koh, J. (2001). Is empowerment really a new concept? International Journal of Human 
Resource Management, 12(4), pp.684-695.

Lengnick-Hall, C. A. (1996). Customer contribution to quality: A different view of the customer-oriented firm. Academy of Management Review, 21(3), pp. 791-824.

Lovelock, C.H. \& Young, R.F. (1979). Look to consumers to increase productivity. Harvard Business Review, (May-June), pp.168-179.

Lusch, R. F., \& Vargo, S. L. (2006). Servicedominant logic: reactions, reflections and refinements, 6(3), pp. 281-288.

Maynard, M.T., Gilson, L.L. \& Mathieu, J.E. (2012). Empowerment--Fad or Fab? A Multilevel Review of the Past Two Decades of Research. Journal of Management, 38(4), pp.1231-1281.

Mills, P.K., Chase, R.B. \& Margulies, N. (1983). Motivating the Client/Employee System as a Service Production Strategy. The Academy of Management Review, 8(2), pp.301.

Mills, P.K. \& Moberg, D.J. (1982). Perspectives on the Technology of Service Operations. Academy of Management Review, 7(3), pp.467-478.

Ouschan, R., Sweeney, J.C. \& Johnson, L.W. (2000). Dimensions of patient empowerment: implications for professional services marketing. Health marketing quarterly, 18(1-2), pp.99-114.

Parish, J. T. \& Holloway, B. B. (2010) "Consumer relationship proneness: a reexamination and extension across service exchanges", Journal of Services Marketing, 24(1), pp.61-73.

Prahalad, C.K. \& Ramaswamy, V. (2000). Coopting Customer Competence. Harvard Business Review, January-Fe, p.R00108.

Prahalad, C.K. \& Ramaswamy, V. (2004). Cocreation experiences: The next practice in value creation. Journal of Interactive Marketing, 18(3), pp.5-14.

Pranic, L. \& Roehl, W. S. (2012). Rethinking service recovery: a customer empowerment (CE) perspective. Journal of Business Economics and Management, 13(2), pp. 242-260.

Prentice, C., Han, X. Y \& Li, Y. Q. (2016) Customer Empowerment to Co-Create Service Designs and Delivery: Scale Development and Validation, Services Marketing Quarterly, 37(1), pp.36-51.
Raaij, W.F. V. \& Pruyn, A.T.H. (1998). Customer Control and Evaluation of Service Validity and Reliability. Psychology \& Marketing, 15(8), pp.811-832.

Seibert, S.E., Wang, G. \& Courtright, S.H. (2011). Antecedents and consequences of psychological and team empowerment in organizations: A metaanalytic review. The Journal of applied psychology, 96(5), pp.981-1003.

Smith, N. C. \& and Cooper-Martin, E. (1997). Ethics and Target Marketing: The Role of Product Harm and Consumer Vulnerability. Journal of Marketing, 61(3), pp. 1-20.

Song, J.H. \& Adams, C.R. (1993). Differentiation through Customer Involvement in Production or Delivery. Journal of Consumer Research, 10(2), pp.4-12.

Thomas, K.W. \& Velthouse, B.A. (1990). Cognitive Elements of Empowerment: An "Interpretive" Model of Intrinsic Task Motivation. The Academy of Management Review, 15(4), pp.666-681.

Vargo, S.L. \& Lusch, R.F. (2004). Evolving to a New Dominant Logic for Marketing. Journal of Marketing, 68(1), p. 1-17.

Vargo, S.L. \& Lusch, R.F. (2008). Servicedominant logic: continuing the evolution. Journal of the Academy of Marketing Science, 36(1), pp.110.

Vargo, S. L., Lusch, R. F. (2017). Service-dominant logic 2025, International Journal of Research, 34(1), pp 46-67.

Wathieu, L., Brenner, L, Carnon, Z, Chattopadhyay, A., Wetenbroch,K, Drolet, A., Gourville, J., Muthukrishnan, A. V., Novemsky, N., Ratner, R., Wu, G. (2002). Consumer Control and Empowerment: A Primer. Marketing Letters / Kluwer Academic Publishers. Manufactured in The Netherlands, 13(3), pp.297-305.

Wind, J. \& Rangaswamy, A. (2001). Customerization: The next revolution in mass customization. Journal of Interactive Marketing, 15(1), pp.13-32.

Wolf, M., Albinsson, P. A. and Becker, C. (2015), Do-It-Yourself Projects as Path toward Female Empowerment in a Gendered Market Place. Psychol. Mark., 32 (2), pp. 133-143 
Yen, H. R., Gwinner, K. P., \& Su, W. (2004). The impact of customer participation and service expectation on Locus attributions following service failure. International Journal of Service Industry Management, 15(1), 7-26.

Yim, C. K., Tse, D. K. \& Chan, K. W. (2008). Strengthening Customer Loyalty Through Intimacy and Passion: Roles of Customer-Firm Affection and Customer-Staff Relationships in Services. Journal of Marketing Research, 45(6), pp. 741-756.

Zimmerman, M. A. (1990). Taking aim on empowerment research: On the distinction between individual and psychological conceptions. American Journal of Community Psychology, 18 (1), pp. 169-177.

Zimmerman, M.A. (1995). Psychological Empowerment : Issues and Illustrations 1. American Journal Of Community Psychology, 23(5), pp.581-599.

Zimmerman, M.A. \& Rappaport, J. (1988). Citizen participation, perceived control, and psychological empowerment. American Journal of Community Psychology, 16(5), pp.725-750. 